\title{
CHARITY PUNISHMENT IN ISLAMIC BOARDING SCHOOL TO IMPROVING SANTRI DISCIPLINE
}

\author{
Ibnu Habibi ${ }^{1}$, Triyo Supriatno ${ }^{2}$ \\ Sekolah Tinggi Ilmu Tarbiyah Muhammadiyah Bojonegoro, Indonesia ${ }^{1}$ \\ Pascasarjana Universitas Islam Negeri Maulana Malik Ibrahim Malang, Indonesia ${ }^{2}$ \\ nizamhabibi259@gmail.com, tryo@pai.uin.malang.ac.id
}

\begin{abstract}
The purpose of this article is to analyze and describe the charity punishment in improving the discipline of santri at the Al Amin Bojonegoro, Muhammadiyah Islamic Boarding School (MBS). This article uses a type of qualitative research using a descriptive-analytic approach. To obtain the technical data used were observation, interviews, and documentation. The results of this article indicate that the forms of punishment in $\mathrm{Al}$ Amin Bojonegoro Islamic Boarding School are t ta'zir, 'iqab, and charity, all of which aim to improve the discipline of students. The charity punishment is more prioritized in enforcing the sentence of santri in various kinds of activities, namely worship activities, teaching and learning activities in class, and activities in the dormitory in terms of shared time and order. This article's results are expected to become a reference material in enforcing discipline in Islamic institutions or informal educational institutions. Further research can be developed on the effectiveness of charity punishment in the domain of santri, which this paper can be used as reference material.
\end{abstract}

Keywords: Charity Punishment, Santri Discipline, Islamic Boarding School

\begin{abstract}
Abstrak
Tujuan artikel ini adalah untuk menganalisis dan mendeskripsikan bukuman Sedekab dalam meningkatkan kedisiplinan santri di Pondok. Pesantren Mubammadiyah Boarding School (MBS) Al Amin Bojonegoro. Artikel ini menggunakan jenis penelitian kualitatif dengan menggunakan pendekatan deskriptik analitik. Untuk memperoleh data tehnik yang digunakan adalah observasi, wawancara dan dokumentasi. Hasil penelitian ini menunjukekan bahwa bentuk bukuman yang ada di Pondok Pesantren MBS Al Amin Bojonegoro adalabt ta'zir, 'iqab dan sedekah, yang semuanya bertujuan untuk meningkatkan disiplin santri. Adapun bukuman sedekah lebih diprioritaskan dalam penegakan disiplin santri diberbagai macam kegiatan, yaitu kegiatan ibadah, kegiatan belajar mengajar di kelas, dan aktifitas di asrama dalam hal waktu dan ketertiban bersama. Hasil penelitian ini diharapkan menjadi bahan referensi dalam penegakan kediplinan dilembaga islam ataupun di lembaga pendidikan formal sehingga berikutnya bisa dikembangan pula penelitian tentang efektifitas bukuman shodaqah dalam kedisiplinan santri yang mana tulisan ini bisa digunakan sebagai bahan rujukan.
\end{abstract}

Kata Kunci : Hukuman Sedekah, kedisiplinan Santri, Pesantren 


\section{INTRODUCTION}

In the world of education, the term of punishment is often heard ${ }^{1}$. In general, punishment usually occurs because of a crime, such as murder, theft, torture, etc. Unlike in the field of education, discipline is given to students (santri) who violate the norms and rules that have been established in educational institutions. Punishment is applied so that students are deterred or as a lesson not to repeat the wrongful act that is feared. It will become a habit that can damage their lives shortly because punishment is an educational tool that is also needed in education ${ }^{2}$.

From an Islamic perspective, the principle of punishment is mentioned repeatedly in the verses of the Qur'an and hadith ${ }^{3}$. When Allah talks about the beauty Of heaven as a reward for good human deeds, it is often accompanied by the threat of hell's torment as punishment for humans' bad acts. ${ }^{4}$

Usually, if informal or non-formal educational institutions, there is a predetermined sentence, then there are also rules that must be applied. One of the functions of punishment is to increase discipline ${ }^{5}$. As Supardi and Aqila say in their book Creative Ideas for Educating Children for Busy Parents, rules as good as they are, it requires discipline ${ }^{6}$.

The word discipline comes from the Latin discern, which means learning. From this word, the term discipline appears, which means teaching or training. Along with the changing times and the times, the word discipline is now interpreted in various ways, namely as obedience to regulations or subject to supervision and court and interpreted as training to develop oneself to behave in an orderly manner. ${ }^{7}$

${ }^{1}$ Wang Jiayi and Cheng Ling, 'Reviewing Teacher Evaluation of Rewards and Punishments: The Overview of Chinese Teacher Evaluation Research', Education Research International 2012 (12 December 2012): 1-16, https://doi.org/10.1155/2012/184640; Siti Misriyah, 'Implementation and Implication of Reward and Punishment Toward Character Education at Senior High School in Pemalang', Hikmatuna: Journal for Integrative Islamic Studies 1, no. 1 (2015), http://e-journal.stain-pekalongan.ac.id/index.php/hikmatuna/article/view/473; Rusmilawati Windari, 'Penggunaan Hukum Disiplin (Corporal Punishment) pada Anak Di Lingkungan Sekolah Dalam Perspektif Hukum Pidana di Indonesia', Jurnal Hukum PRIORIS 4, no. 3 (18 May 2016): 303-28, https://trijurnal.lemlit.trisakti.ac.id/prioris/article/view/388.

2 Muhammad Anas Ma`arif and Ari Kartiko, 'Fenomenologi Hukuman di Pesantren: Analisis Tata Tertib Santri Pondok Pesantren Daruttaqwa Gresik', Nadwa 12, no. 1 (22 June 2018): 181-96, https://doi.org/10.21580/nw.2018.12.1.1862; Muhammad Husnur Rofiq, 'Kedisiplinan Siswa Melalui Hukuman Dalam Perspektif Stakeholder Pendidikan', Nidhomul Haq : Jurnal Manajemen Pendidikan Islam 2, no. 2 (2017): 8294, https://doi.org/10.31538/ndh.v2i2.25; Baharuddin, Moh Makin, and Abdul Qodir Shaleh, Pendidikan bumanistik. (konsep, teori, dan aplikasi praksis dalam dunia pendidikan) (Yogyakarta: Ar-Ruzz Media, 2007), 74.

${ }^{3}$ Raihan Raihan, 'Penerapan Reward Dan Punishment Dalam Peningkatan Prestasi Belajar Pendidikan Agama Islam Terhadap Siswa SMA Di Kabupaten Pidie', DAYAH 2, no. 1 (1 January 2019): 115-30, https://doi.org/10.22373/jie.v2i1.4180; Fajar Malik, Holistika Pemikiran Pendidikan (Jakarta: Raja Grafindo Persada, 2005). 2007).

${ }^{4}$ Tjipta Susana, Familia, and Tim Pustaka, Mempertimbangan Hukuman Pada Anak (Jogjakarta: Kanisius,

${ }^{5}$ Candra Wijaya, M. Luthfie Ramadhani, and Edi Jatmiko, 'Persepsi Guru Tentang Reward and Punishment Dan Implementasinya Dalam Pembelajaran Di Man Ii Model Medan’, Naz̧hruna: Jurnal Pendidikan Islam 3, no. 1 (21 February 2020): 121-37, https://doi.org/10.31538/nzh.v3i1.521; Thiwari Ashwini, 'Teachers, Discipline and The Corporal Punishment Ban In Delhi India' (Dissertation, Pennsylvania, Pennsylvania State University, 2014).

${ }^{6}$ Supardidan Aqila Smart, Ide-Ide Kreatif Mendidik. Anak Bagi Orang Tua Sibuk (Yogjakarta: Ar-Ruz Media, 2010), 39 .

7 Ngainun Naim, Character Building: Optimalisasi Peran Pendidikan Dalam Pengembangan Ilmu\& Pembentukan Karakter Bangsa, (Jogjakarta: Ar-Ruz Media, 2012), 142. 
Among the non-formal educational institutions in Indonesia are pesantren which also apply various rules and regulations, while punishment is used as a form of sanction for violations. Islamic Boarding School is one of the educational institutions that is engaged in religion-based education ${ }^{8}$. The education that is organized is not just a process of transferring knowledge and expertise but also transferring moral values and beliefs from the previous generation to the next generation. Pesantren is also a social and religious institution whose caregivers are also community leaders, which is a reference of legitimacy (legality) to their citizens. The pesantren's learning process looks democratic because regardless of age, without attendance and not grouped based on intellectual level'.

Islamic Boarding School is the oldest Islamic educational institution and religious institution in Indonesia apart from Dayah, Rangkang, Meunasah, and Surau ${ }^{10}$. Its development comes from the community and the community. Meanwhile, most of the pesantren emerged as a form of reaction to specific life patterns that were considered vulnerable, so pesantren's emergence was a very long part ${ }^{11}$. On the other hand, the pesantren's growth begins with recognizing a particular community environment for the advantages of absolute knowledge of a kiai and his holiness. Therefore many of the local people come to study with him ${ }^{12}$. Because of their significant influence on the surrounding community, many of the kiai have become figures in a village and are even considered the initiators of establishing a town. ${ }^{13}$

Pesantren also have rules that must be applied. In general, the rules and types of punishment are made based on mutual agreement and are decided together through deliberation. Laws and punishments are terms that are interrelated and interrelated with one another ${ }^{14}$. There are rules, there are also penalties, namely actions that will be given to violators of these rules. However, in CandraWijaya et al's research, it is said that punishment is not necessary when other instruments can be used to maintain student's faith to continue to believe or to pray to Allah SWT. A new punishment is needed and can be carried out when it

${ }^{8}$ Bianca J. Smith, 'Sexual Desire, Piety, and Law in a Javanese Pesantren: Interpreting Varieties of Secret Divorce and Polygamy', Anthropological Forum 24, no. 3 (3 July 2014): 227-44, https://doi.org/10.1080/00664677.2014.947918.

${ }^{9}$ Raihani, 'Report on Multicultural Education in Pesantren', Compare: A Journal of Comparative and International Education 42, no. 4 (1 July 2012): 585-605, https://doi.org/10.1080/03057925.2012.672255.

10 Azyumardi Azra, Pendidikan Islam: Tradisi Dan Modernisasi Di Tengah Tantangan Milenium III Jakarta: Kencana, 2012), 148; Zamakhsyari Dhofier, Tradisi pesantren: studi pandangan bidup kyai dan visinya mengenai masa depan Indonesia, Cet. 8 rev (Jakarta: LP3ES, 2011); Ziemek Manfred, Pesantren Dalam Perubahan Sosial (Jakarta: P3M, 1983); Mujamil Qomar, Pesantren: dari transformasi metodologi menuju demokratisasi institusi (Ciracas, Jakarta: Erlangga, 2005).

11 Hanun Asrohah, 'The Dynamics of Pesantren: Responses Toward Modernity and Mechanism in Organizing Transformation', Journal of Indonesian Islam 5, no. 1 (1 June 2011): 66-90, https://doi.org/10.15642/JIIS.2011.5.1.66-90; Abdul Malik Karim Amrullah, 'Perubahan Dan Perkembangan Model Pesantren', El-Hikmah 0, no. 0 (27 April 2013), http://ejournal.uinmalang.ac.id/index.php/elhikmah/article/view/2238.

12 Nana Herdiana Abdurrahman, 'Character Education in Islamic Boarding School- Based Sma Amanah', Jurnal Pendidikan Islam 2, no. 2 (21 June 2016): 287-305, https://doi.org/10.15575/jpi.v2i2.791; Hasbi Indra, 'Salafiyah Curriculum at Islamic Boarding School in the Globalization Era', TARBIYA: Journal of Education in Muslim Society 4, no. 1 (13 June 2017): 74-88, https://doi.org/10.15408/tjems.v4i1.4960.

${ }^{13}$ Hasyim Asy'ari et al., 'The Leadership of Revivalist Kiai: Kiai's Leadership Behaviours in Pesantren Shuffah Hizbullah Al-Fattah Cileungsi Bogor', Jurnal Pendidikan Islam 6, no. 2 (27 December 2017): 427-47, https://doi.org/10.14421/jpi.2017.62.427-447.

14 Ishaq Syahid, 'Penerapan Ta`zir Pada Pembentukan Ahlak Santri Pondok Pesantren Syaikhona Muhammad Cholil Bangkalan’ (Tesis, Surabaya, UIN Sunan Ampel Surabaya, 2015). 
is thought that almost no other instruments can be used to nurture, foster, or awaken students from the mistakes they have committed ${ }^{15}$.

Punishment is one of the educational measurement instruments for the academic functional quality of students with problems and achievements, in this case, the punishment is early vaccination in the context of educating those with problems ${ }^{16}$. Therefore, it is the duty and responsibility of all parties, especially academics and education practitioners, to closely monitor how education management has been running concerning punishment in academic activities in various educational institutions, including Islamic boarding schools.

Therefore, it is in line with previous research that states that punishment can deter perpetrators. So the researchers are interested in analyzing in-depth and practically charity as a form of punishment in enforcing students' discipline.

\section{THEORY}

\section{Concept of Punishment in Islam}

In Islam, there are commands and prohibitions, which require followers to obey orders and not violate prohibitions, both from Allah and from the Messenger of Allah. If someone obeys orders, they will get a reward in the form of reward, whereas if someone violates the prohibition they will be given punishment. One form of punishment in Islam is kafarat (redemption). The concept of charity punishment is emphasized by the application of kafarat, which prioritizes social punishment rather than individual physicalpunishment, for example; in case of accidental murder, the kafarat gives priority to the release of the Muslim slave, so if he cannot do it then fast for two consecutive months.

For example in the case of zihar. Zihar comes from the word ظל which is zhahr meaning back, (saying to his wife, "you are like my mother's back," meaning that the wife is haram for him) that is if the husband says as above it is divorce, the greatest that happens at the time of the Jahiliyah ${ }^{17}$. Zihar is a word used to equate a wife with her mother, this event in the time of Jahiliyah meant divorce, if a husband pronounces you like my mother's back, then a husband has forbidden his wife because the wife has been equated like a mahram which is baram to marry, namely her mother, That is why when a husband has married, a husband may not interfere with his wife until the husband pays kafarat. After paying the kafarat zihar it is no longer an act of zihar, and it is permissible to interfere with his wife if he has paid one of the kaffarat that has been prescribed by Allah.

Furthermore, in Surah al-Mujadallah verses 3 (three) and 4 (four) it is also explained how the law of a person who drops zihar on his wife. This verse also explains what kafarat must be done after the husband's statement of zihar if the husband wants to come back again to interfere with his wife. Therefore, Allah SWT not only forbids but warns not to do zihar again by setting kafarat in verses 3 and $4^{18}$ :

${ }^{15}$ Wijaya, Ramadhani, and Jatmiko, 'Persepsi Guru Tentang Reward and Punishment Dan Implementasinya Dalam Pembelajaran Di Man Ii Model Medan'.

16 B. R Hergenhahn and Matthew H Olson, Theories of learning = teori belajar, trans. Triwibowo, 6th ed. (Jakarta: Prenada Media Grup, 2016).

17 Al-Maragi Ahmad Mustofa, Terjemah Tafsir Al-Maragi, trans. Abu Bakar Bahrun (Semarang: Thoha Putra, 1993), 3.

18 Al-Qur`an (Jakarta: Kementerian Agama RI, 2010), Surah Al-Mujadalah 3-4. 
"People who marry their wives, then they want to take back what they say, then (obliged on it) to free a slave before the two husbands and wife mingle. This is what was taught to you, and Allah knows best what you are doing, (3) Whoever does not get (slave), then (obliged to him) fast two consecutive months before the two mixes. So whoever is not in power (it is obligatory for him) to feed sixty poor people. This is so that you may have faith in Allah and His Messenger. And these are the laws of Allah, and for the unbelievers there is a very painful torment."(4).

In the hadith it is stated "It is narrated that the Prophet SAW, said to Khaulah after the fall of the above verse that: "let him make a servant free". Khaulah said: "he is incapable". The Prophet told him to fast for two consecutive months. The wife answered again: "He is an old man, he will not be able to". Then, the Prophet SAW, said again: "If so, let him feed sixty poor people". Khaulah for the third time answered, "He does not have". The Prophet said: "if so, we help him partly". Then Khaulah replied: "from me is part of". (Narrated by Abu Daud). ${ }^{19}$

In other cases, accidental killing according to Islamic law is an act committed by a person without an intentional element resulting in the death of another person or a murder that occurs without the intention of breaking the law, and there is no element of intent ${ }^{20}$. The sanction of accidental murder in Islamic law, including 1) Diyat punishment. Diyat is a number of assets that the perpetrator charges for the victim's family (aqilab) as a substitute for punishment. Although it is a punishment, a diyat is property given to the victim's family or family, not to the state treasury. The punishment of accidental murder is not obliged to be qishas, it is only obliged to pay a light fine (diyat), this fine is required for the family who kills, not for the person who kills. They paid in installments in three-year terms, each year the family had to pay one-third. ${ }^{21}$ 2) The kifarat punishment for negligent murder is the main penalty. The type, as stated in the discussion about syibulam, is to liberate the believer's servant. If the servant is not found, then substitute punishment is fasting for two consecutive months.

\section{METHOD}

This article uses a qualitative research type with an analytic-descriptive design. When this research was conducted in 2019 before the pandemic period and took place at the Muhammadiyah Al-Amin Bojonegoro Islamic Boarding School (MBS). The informants in this study were the kiai, the head of the pesantren, the students and the religious teachers. Data collection techniques used formal and non-formal interviews, documentation and participant observation. Data analysis using the Bodgan and Taylor ${ }^{22}$ model, namely by triangulating data, sources and methods. Pesantren (MBS) Al Amin Bojonegoro is a modern Islamic boarding school which was established on May 3, 2015 and is located on Jl. BasukiRahmat No. 40

${ }^{19}$ Moh Quraish Shihab, Tafsir Al-Misbah (Jakarta: Lentera Hati, 2005), 475.

20 Zainuddin Ali, Hukum pidana Islam (Yayasan Masyarakat Indonesia Baru, 2003), 24.

${ }^{21}$ Sulaiman Rasjid, Figh Islam (Hukum Figh Islam), (Bandung: Sinar Baru Algesindo, 2012), 430.

22 Robert Bogdan and Sari Knopp Biklen, Qualitative Research for Education: An Introduction to Theory and Methods, 3rd ed (Boston: Allyn and Bacon, 1998); Steven J. Taylor, Robert Bogdan, and Marjorie L. DeVault, Introduction to Qualitative Research Methods: A Guidebook and Resource, Fourth edition (Hoboken, New Jersey: John Wiley \& Sons, Inc, 2016). 
Sukorejo, Bojonegoro subdistrict, Bojonegoro District, has also implemented and prioritized the 'Sedekah' penalty over physical punishment for violations that occurred at the pondok. ${ }^{23}$

\section{RESULT AND DISCUSSION}

\section{Kinds of Punishment is Applied}

Everything that is determined in educational institutions, especially in Islamic Boarding Schools, starts from the rules for both obligations and prohibitions to punishment as a form of sanction for violations, not to frighten students. However, with this binding discipline, it is hoped that the students can be well controlled and do not do their own thing. Likewise, the punishment is actually not meant to hurt and torment the students, but rather to regulate the behavior of the students and educate them to be better.

In the pesantren, if the example and advice are not able to awaken the santri, at that time decisive action must be taken to put the problem in the right place. The firm action is punishment, although this is not good but students must also be punished so that they realize their mistake. Giving charity is prioritized to punish students than $t a^{\prime}$ zir and iqab. Although charity punishment is the lightest because it does not involve physicality, it is better if it is applied. Given that almost all activities in pesantren if there are violations the form of penalty is to pay charity. If charity continues to increase, it can be used for the needs and needs of students, for example; shaving hair together, and outbound activities (recreation) after the semester exams. So the charity punishment is from the santri, by the santri for the santri.

The sentence at Pesantren MBS Al Amin has gone well, because of the good cooperation between the board and the students. Because the rules and sanctions set are the result of mutual agreement between the management and the students. Thus from the research results, it can also be concluded that in Pesantren MBS Al Amin Bojonegoro there are two types of punishment, namely ${ }^{24}$ :

Ta'zir in Islamic law has been determined as a form of syar'i violation that is independent of budud and jinayat crimes, but the level of sanctions has not been determined by sharia, so sanctions are left to the authorities (rulers) to determine the type of sanctions. Ta'zir at Pesantren MBS Al Amin Bojonegoro is considered a type of severe punishment because it is related to disobedience, such as being found out of the hut area (running away) without permission, smoking, and stealing. For this problem, the board and person in charge of the queenship determine the right form of punishment so that the students will be deterred and do not go back to doing it. The punishment is a suspension (returning the students to their parents' house) for 1 week, and if they (students) still repeat it, it is added to 2 weeks, and if they still do it, the last way will be taken, which is to get them out of the hut.

Paying charity: Charity penalties is a form of non-physical sanction that is also applied in pesantren for violating regulations. The amount of charity given depends on the size and size, as well as the form and type of offense. From the researcher's observations, it was found that the charity punishment had a big impact on the behavior of the students. In addition, the charity punishment provides encouragement to always not behave negatively, such as leaving

${ }^{23}$ Wawancara dengan H. Syamsul Huda, M.Pd.IMudir PP MBS Al Amin Bojonegoro, tanggal 16 Februari 2020 pukul 10.00 wib

${ }^{24}$ Wawancara dengan M. Hafidz Syarifuddin, S.Kom, Pj. Kesantrian PP. MBS Al Amin Bojonegoro tanggal 18 Februari 2020. 
the boarding school without permission, skipping time when reciting al-Qur'an memorization, being late in congregational prayers and other behavior that deviates from the rules of the boarding school.

Table 1. Kinds of charity (sedekah) punishment in Pesantren MBS Al Amin Bojonegoro

\begin{tabular}{lll}
\hline No. & \multicolumn{1}{c}{ Types of Punishment } & \multicolumn{1}{c}{ Offenses } \\
\hline 1. & Exit lodge without permission & 1 week suspension \\
2. & Steal Money over 100,000 Suspension for & 1 week and replace \\
3. & Steal money brought 100.00 & replace \\
4. & Do not participate in congregational prayers & Sedekah Rp. 20,000,- \\
& (without $u d$ rur) & \\
5. & Praying late in congregation & SedekahRp. 1,000,- \\
6. & Clothes Fall on the Clothesline & SedekahRp. 2.500,- \\
7. & Clothes scattered out of place & SedekahRp. 2.500,- \\
8. & Clothes Not neatly arranged in the cupboard & SedekahRp. 2.000,- \\
9. & Shoes or sandals are untidy & SedekahRp. 1.000,- \\
10. & Littering & SedekahRp. 10.000,- \\
11. & Coming to the lodge was not in accordance & SedekahRp. 50.000,- \\
& with the provisions (too late) after the permit & \\
& was issued. & \\
12. & crowded when praying in congregation & SedekahRp. 10.000,- \\
13. & Not speaking Arabic at certain times and & SedekahRp. 1.000,- \\
& places & \\
14. & Coming late to school & Cleaning the classroom yard \\
15. & Do not wash dishes after eating. & Wash dishes for all members of the \\
& & room for 3 days \\
\hline
\end{tabular}

\section{Implementation of Charity Punishment in Pesantren (MBS) Al Amin Bojonegoro}

The characteristics that are generally owned by Islamic boarding schools are the existence of Kiai (pesantren caregivers), the existence of a mosque as a center for religious and learning activities, santri, namely people who learn, and the existence of a dormitory as a residence for the students, and the yellow book (kitab kuning) as a reference for learning students ${ }^{25}$.

25 Sharyn Graham Davies, 'Gender and Power in Indonesian Islam: Leaders, Feminists, Sufis and Pesantren Selves', Theology \& Sexuality 22, no. 1-2 (16 May 2016): 128-30, https://doi.org/10.1080/13558358.2017.1296699; Claire-Marie Hefner, 'Models of Achievement: Muslim Girls and Religious Authority in a Modernist Islamic Boarding School in Indonesia', Asian Studies Review 40, no. 4 (1 October 2016): 564-82, https://doi.org/10.1080/10357823.2016.1229266; Eti Nurhayati and Yayah Nurhidayah, 'Multicultural Value in the Traditional Islamic Boarding School, Bina Insan Mulia (BIMA), Cirebon, Indonesia', Nadwa 13, no. 1 (29 August 2019): 165-78, https://doi.org/10.21580/nw.2019.1.1.3509. 
The Islamic boarding school also has several activities that have been scheduled for daily, weekly, and monthly activities, as well as mandatory and sunnah activities ${ }^{26}$. In these activities, there are regulations and sanctions so that the activities run well so that students are highly disciplined in carrying out activities in the pesantren. The effectiveness of the charity punishment applied in Islamic boarding schools has a high effect, as evidenced by the fact that students who were initially inactive became active in participating in activities. The large number of sedekah or frequent punishment of ta'sir and iqab makes the santri deterred and embarrassed when the name of the student is mentioned or posted on the bulletin board because he is being punished by the ustadz (administrator) ${ }^{27}$.

As for the implementation of discipline, it should ideally cover all aspects of human life activities, because if one aspect occurs indiscipline it will affect other aspects. Because of that, in this discussion, the writer needs to provide a "limit" in accordance with the major theme of this paper. These limitations include discipline in worship, discipline in management (managing) time, discipline in learning, and discipline in obeying rules ${ }^{28}$.

The implementation of sedekah punishment in improving student discipline in Pesantren MBS Al Amin Bojonegoro, are as follows;

In the implementation of worship. Although every human activity can be intended for worship, this article only describes the discussion of prayer services. A prayers are the starting point for worship, as well as the first practice that will be judged (calculated) on the Day of resurrection. Prayer is an act of a believer in situations where he faces God. So when Prayer are performed diligently and continuously it will become an effective human spiritual education tool, renewing and nurturing the soul, and encouraging the growth of consciousness. Likewise, when praying with the solemnity it will keep a person away from all things that are vile and evil. This is as explained by Allah:

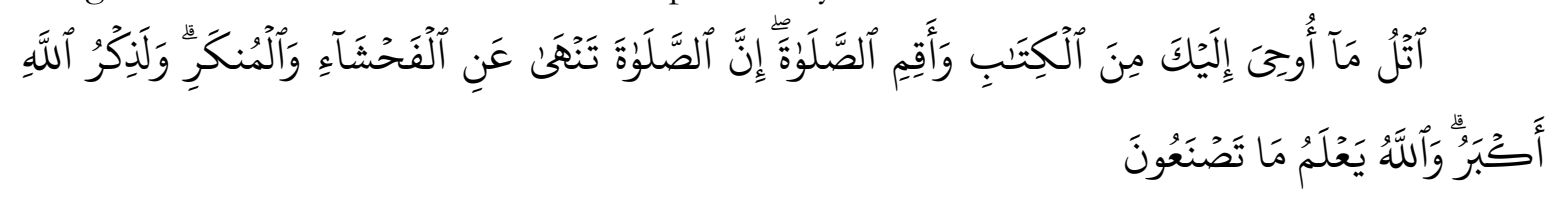

Meaning: "Read what has been revealed to you, namely the Holy Book (Al Qur'an), and establish prayers. Indeed, prayer prevents (actions) heinous and evil. And actually remembering Allah (prayer) is greater (its virtue than other acts of worship). And Allah knows what you do". (Surah al -Ankabut: 45)

When viewed from a disciplinary perspective, prayer worship is a positive education that can make a person and society live regularly. In connection with this, prayer is highly emphasized in pesantren, in addition to other worship. Therefore, it is natural that students in the pesantren are required to always attend congregational prayers on time. And one of the

${ }^{26}$ Zamakhsyari Dhofier, 'Traditional Islamic Education in the Malay Archipelago: Its Contribution to the Integration of the Malay World', Indonesia Circle. School of Oriental \& African Studies. Newsletter 19, no. 53 (1 November 1990): 19-34, https://doi.org/10.1080/03062849008729746; Abdurrahman Wahid, 'Dinamisasi Pendidikan Pesantren', n.d., 4.

27 Muhammad Anas Ma'arif, 'Hukuman (Punishment) Dalam Perspektif Pendidikan Di Pesantren', Ta'allum: Jurnal Pendidikan Islam 5, no. 1 (1 June 2017): 1-20, https://doi.org/10.21274/taalum.2017.5.1.1-20.

28 Windari, 'Penggunaan Hukum Disiplin (Corporal Punishment) pada Anak Di Lingkungan Sekolah Dalam Perspektif Hukum Pidana di Indonesia'.

${ }^{29}$ Al-Qur`an, Surah Al-Ankabut. 45. 
heaviest violations at the MBS Al Amin Bojonegoro boarding school is not participating in congregational prayers.

In managing time. Scheduling all daily activities is difficult and sometimes inappropriate or inappropriate. By gradually getting used to it will generate a disciplined attitude, especially in terms of managing time. In pesantren, the rules/regulations that have been set will educate students to be disciplined, as are the rules that require students to be on time in-class learning and activities outside the classroom, as well as obligatory prayers five times on time. If the students obey the rules in the boarding school well, this will also become a good habit after living outside the boarding school and the community later. The implementation of punishment in increasing the discipline of students in managing their time basically has a good purpose, but in other cases, there are still many students who violate the rules and sometimes there are also students who deliberately do it and they prefer to be fined/punished.

In obeying the rules. Discipline is a must in Islamic boarding schools. To ensure smoothness and order in the educational process, Islamic boarding schools usually formulate rules that contain regulations that must be obeyed by all students. Apart from adhering to the rules of the boarding school, students are also required to understand and comply with the prevailing pesantren cultural patterns. In order to understand the culture or unwritten rules, students can see the examples given by the Kiai and the ustadr, so that good examples will always be implemented and always try not to violate them. As for Islamic boarding schools that carry out discipline permissively (no concern/indifference) and provide more freedom, there are also norms that must be understood and obeyed by all parties, for example, a santri may not speak carelessly or go back and forth in and out of class, bringing food and bringing drinks to class as they can interfere with the progress of lessons.

The existence of regulation will certainly be accompanied by punishment. Regulations are a form of an effort to discipline students, while punishment is a form of sanction for students who violate this rule. If students always obey the rules of the Islamic boarding school, then the students will always obey the rules outside the boarding school. However, in practice, some students are still lacking in carrying out the discipline. So it does not function effectively, because of the varied forms of regulations that are implemented in the Islamic boarding schools ${ }^{30}$.

Student discipline in learning. The learning process in pesantren usually occurs every day at all times, from morning to midnight, according to the subject matter. The daily activities at the pesantren usually start before dawn until the students sleep. Starting with the preparation for the morning prayer in congregation, then continue reading the al-Qur'an, the morning prayer until the afternoon according to the class or level. Such education has a great influence on the life of the santri. The students sometimes hold muthalaab on the material that has been delivered by the ustadz or Kiai, either before or after the learning process. The application of punishment can spur the students 'motivation to be more active in learning so

30 Siti Yumnah, 'Construction of Islamic Boarding Shcool in Developing Moderate Islam', Naz̧hruna: Jurnal Pendidikan Islam 3, no. 2 (24 July 2020): 232-46, https://doi.org/10.31538/nzh.v3i2.614; Mas'odi Mas'odi, 'Tradition of Kiai Kinship at Islamic Boarding School in Madura (Study on Trah, Kiai Kinship, Islamic Boarding School in Sumenep)', Edukasia: Jurnal Penelitian Pendidikan Islam 14, no. 1 (24 June 2019): 205-20, https://doi.org/10.21043/edukasia.v14i1.3641. 
that the students' discipline in learning also increases. The typical learning methods that exist in Islamic boarding schools, namely memorization, sorogan, and bandongan, do not function properly if students do not have a disciplined attitude in learning. The form of punishment used to discipline students in studying at this boarding school is Sedekah. Although the type of punishment according to the author is less effective, there are many students who have high awareness to always follow the lessons in the Islamic boarding school.

\section{CONCLUSION}

The MBS Al Amin Bojonegoro Islamic boarding school applies several forms of punishment, including $t a^{\prime} z i r$ and sedekah/charity, by providing special activities for students who violate the rules set by Pesantren MBS Al Amin Bojonegoro. Ta'zir penalties, such as washing dishes in all room members, taking out the trash for a month, and suspension (sending students to their homes) for one or two weeks. Meanwhile, the amount of punishment (fines) is determined and adjusted to the size of the students' errors in violating the rules of the pesantren. From that statement, it turns out that the punishment provides an impetus for always not behaving negatively, such as littering, leaving the cottage without permission, skipping while reciting the al-Qur'an memorization, and other behaviors that deviate from the rules of the Islamic Boarding School because this is a measure of the success of education, especially in PP MBS Al Amin Bojonegoro.

The implementation of the charity punishment in Pesantren MBS Al Amin Bojonegoro is carried out in various activities at the Islamic Boarding School, including: in the performance of worship, in managing time, in obeying regulations, and in-class learning activities, which are detailed in the form of obligatory prayers five times in congregation in mosques, studying at school, diniyah, reading kitab kuning, Tabfidzul Qur'an, Qiro'ah training, and mubadharah and other activities. The research results prove that charity's punishment is very useful in disciplining students because they are also assisted by the students' high selfawareness to always participate in every activity at the Islamic boarding school/Pesantren.

\section{REFERENCES}

Abdurrahman, Nana Herdiana. 'Character Education in Islamic Boarding School- Based Sma Amanah'. Jurnal Pendidikan Islam 2, no. 2 (21 June 2016): 287-305. https://doi.org/10.15575/jpi.v2i2.791.

Ahmad Mustofa, Al-Maragi. Terjemah Tafsir Al-Maragi. Translated by Abu Bakar Bahrun. Semarang: Thoha Putra, 1993.

Ali, Zainuddin. Hukum pidana Islam. Yayasan Masyarakat Indonesia Baru, 2003.

Al-Qur`an. Jakarta: Kementerian Agama RI, 2010.

Amrullah, Abdul Malik Karim. 'Perubahan Dan Perkembangan Model Pesantren'. El-Hikmah 0, no. $0 \quad$ (27 April 2013). http://ejournal.uinmalang.ac.id/index.php/elhikmah/article/view/2238.

Aqila Smart, Supardidan. Ide-Ide Kreatif Mendidik Anak Bagi Orang Tua Sibuk. Yogjakarta: ArRuz Media, 2010. 
Asrohah, Hanun. 'The Dynamics of Pesantren: Responses Toward Modernity and Mechanism in Organizing Transformation'. Journal of Indonesian Islam 5, no. 1 (1 June 2011): 66-90. https://doi.org/10.15642/JIIS.2011.5.1.66-90.

Asy'ari, Hasyim, Ades Marsela, Agung Pardini, and Firda Amelia. 'The Leadership of Revivalist Kiai: Kiai's Leadership Behaviours in Pesantren Shuffah Hizbullah AlFattah Cileungsi Bogor'. Jurnal Pendidikan Islam 6, no. 2 (27 December 2017): 427-47. https://doi.org/10.14421/jpi.2017.62.427-447.

Azra, Azyumardi. Pendidikan Islam: Tradisi Dan Modernisasi Di Tengah Tantangan Milenium III. Jakarta: Kencana, 2012.

Baharuddin, Moh Makin, and Abdul Qodir Shaleh. Pendidikan bumanistik (konsep, teori, dan aplikasi praksis dalam dunia pendidikan). Yogyakarta: Ar-Ruzz Media, 2007.

Bogdan, Robert, and Sari Knopp Biklen. Qualitative Research for Education: An Introduction to Theory and Methods. 3rd ed. Boston: Allyn and Bacon, 1998.

Davies, Sharyn Graham. 'Gender and Power in Indonesian Islam: Leaders, Feminists, Sufis and Pesantren Selves'. Theology \& Sexuality 22, no. 1-2 (16 May 2016): 128-30. https://doi.org/10.1080/13558358.2017.1296699.

Dhofier, Zamakhsyari. Tradisi pesantren: studi pandangan hidup kyai dan visinya mengenai masa depan Indonesia. Cet. 8 rev. Jakarta: LP3ES, 2011.

'Traditional Islamic Education in the Malay Archipelago: Its Contribution to the Integration of the Malay World'. Indonesia Circle. School of Oriental \& African Studies. Newsletter 19, no. $53 \quad(1 \quad$ November 1990): 19-34. https://doi.org/10.1080/03062849008729746.

Hefner, Claire-Marie. 'Models of Achievement: Muslim Girls and Religious Authority in a Modernist Islamic Boarding School in Indonesia'. Asian Studies Review 40, no. 4 (1 October 2016): 564-82. https:// doi.org/10.1080/10357823.2016.1229266.

Hergenhahn, B. R, and Matthew $\mathrm{H}$ Olson. Theories of learning = teori belajar. Translated by Triwibowo. 6th ed. Jakarta: Prenada Media Grup, 2016.

Indra, Hasbi. 'Salafiyah Curriculum at Islamic Boarding School in the Globalization Era'. TARBIYA: Journal of Education in Muslim Society 4, no. 1 (13 June 2017): 74-88. https://doi.org/10.15408/tjems.v4i1.4960.

Ishaq Syahid. 'Penerapan Ta'zir Pada Pembentukan Ahlak Santri Pondok Pesantren Syaikhona Muhammad Cholil Bangkalan'. Tesis, UIN Sunan Ampel Surabaya, 2015.

Jiayi, Wang, and Cheng Ling. 'Reviewing Teacher Evaluation of Rewards and Punishments:

The Overview of Chinese Teacher Evaluation Research'. Education Research International 2012 (12 December 2012): 1-16. https://doi.org/10.1155/2012/184640.

Ma arif, Muhammad Anas, and Ari Kartiko. 'Fenomenologi Hukuman di Pesantren : Analisis Tata Tertib Santri Pondok Pesantren Daruttaqwa Gresik'. Nadwa 12, no. 1 (22 June 2018): 181-96. https://doi.org/10.21580/nw.2018.12.1.1862.

Ma'arif, Muhammad Anas. 'Hukuman (Punishment) Dalam Perspektif Pendidikan Di Pesantren'. Ta'allum: Jurnal Pendidikan Islam 5, no. 1 (1 June 2017): 1-20. https://doi.org/10.21274/taalum.2017.5.1.1-20.

Malik, Fajar. Holistika Pemikiran Pendidikan. Jakarta: Raja Grafindo Persada, 2005.

Manfred, Ziemek. Pesantren Dalam Perubahan Sosial. Jakarta: P3M, 1983. 
Mas'odi, Mas'odi. 'Tradition of Kiai Kinship at Islamic Boarding School in Madura (Study on Trah, Kiai Kinship, Islamic Boarding School in Sumenep)'. Edukasia: Jurnal Penelitian Pendidikan Islam 14, no. 1 (24 June 2019): 205-20. https://doi.org/10.21043/edukasia.v14i1.3641.

Misriyah, Siti. 'Implementation and Implication of Reward and Punishment Toward Character Education at Senior High School in Pemalang'. Hikmatuna: Journal for Integrative Islamic Studies $1, \quad$ no. 1 (2015). http://e-journal.stainpekalongan.ac.id/index.php/hikmatuna/article/view/473.

Naim, Ngainun. Character Building: Optimalisasi Peran Pendidikan Dalam Pengembangan Ilmue Pembentukan Karakter Bangsa,. Jogjakarta: Ar-Ruz Media, 2012.

Nurhayati, Eti, and Yayah Nurhidayah. 'Multicultural Value in the Traditional Islamic Boarding School, Bina Insan Mulia (BIMA), Cirebon, Indonesia'. Nadwa 13, no. 1 (29 August 2019): 165-78. https://doi.org/10.21580/nw.2019.1.1.3509.

Qomar, Mujamil. Pesantren: dari transformasi metodologi menuju demokratisasi institusi. Ciracas, Jakarta: Erlangga, 2005.

Raihan, Raihan. 'Penerapan Reward Dan Punishment Dalam Peningkatan Prestasi Belajar Pendidikan Agama Islam Terhadap Siswa SMA Di Kabupaten Pidie'. DAYAH 2, no. 1 (1 January 2019): 115-30. https://doi.org/10.22373/jie.v2i1.4180.

Raihani. 'Report on Multicultural Education in Pesantren'. Compare: A Journal of Comparative and International Education 42, no. 4 (1 July 2012): 585-605. https://doi.org/10.1080/03057925.2012.672255.

Rasjid, Sulaiman. Fiqh Islam (Hukum Fiqh Islam),. Bandung: Sinar Baru Algesindo, 2012.

Rofiq, Muhammad Husnur. 'Kedisiplinan Siswa Melalui Hukuman Dalam Perspektif Stakeholder Pendidikan'. Nidhomul Haq: Jurnal Manajemen Pendidikan Islam 2, no. 2 (2017): 82-94. https://doi.org/10.31538/ndh.v2i2.25.

Shihab, Moh Quraish. Tafsir Al-Misbah. Jakarta: Lentera Hati, 2005.

Smith, Bianca J. 'Sexual Desire, Piety, and Law in a Javanese Pesantren: Interpreting Varieties of Secret Divorce and Polygamy'. Anthropological Forum 24, no. 3 (3 July 2014): 227-44. https://doi.org/10.1080/00664677.2014.947918.

Taylor, Steven J., Robert Bogdan, and Marjorie L. DeVault. Introduction to Qualitative Research Methods: A Guidebook and Resource. Fourth edition. Hoboken, New Jersey: John Wiley \& Sons, Inc, 2016.

Thiwari Ashwini. 'Teachers, Discipline and The Corporal Punishment Ban In Delhi India'. Dissertation, Pennsylvania State University, 2014.

Tjipta Susana, Familia, and Tim Pustaka. Mempertimbangan Hukuman Pada Anak. Jogjakarta: Kanisius, 2007.

Wahid, Abdurrahman. 'Dinamisasi Pendidikan Pesantren', n.d.

Wijaya, Candra, M. Luthfie Ramadhani, and Edi Jatmiko. 'Persepsi Guru Tentang Reward and Punishment Dan Implementasinya Dalam Pembelajaran Di Man Ii Model Medan'. Ną̧hruna: Jurnal Pendidikan Islam 3, no. 1 (21 February 2020): 121-37. https://doi.org/10.31538/nzh.v3i1.521.

Windari, Rusmilawati. 'Penggunaan Hukum Disiplin (Corporal Punishment) pada Anak Di Lingkungan Sekolah Dalam Perspektif Hukum Pidana di Indonesia'. Jurnal Hukum 
Charity Punishment in Islamic Boarding School to Improving Santri Discipline

PRIORIS 4, no. 3 (18 May 2016): https://trijurnal.lemlit.trisakti.ac.id/prioris/article/view/388.

Yumnah, Siti. 'Construction of Islamic Boarding Shcool in Developing Moderate Islam'. Ną̧huna: Jurnal Pendidikan Islam 3, no. 2 (24 July 2020): 232-46. https://doi.org/10.31538/nzh.v3i2.614. 